\title{
LISTA RECENZENTÓW WSPÓŁPRACUJĄCYCH Z RDSG
}

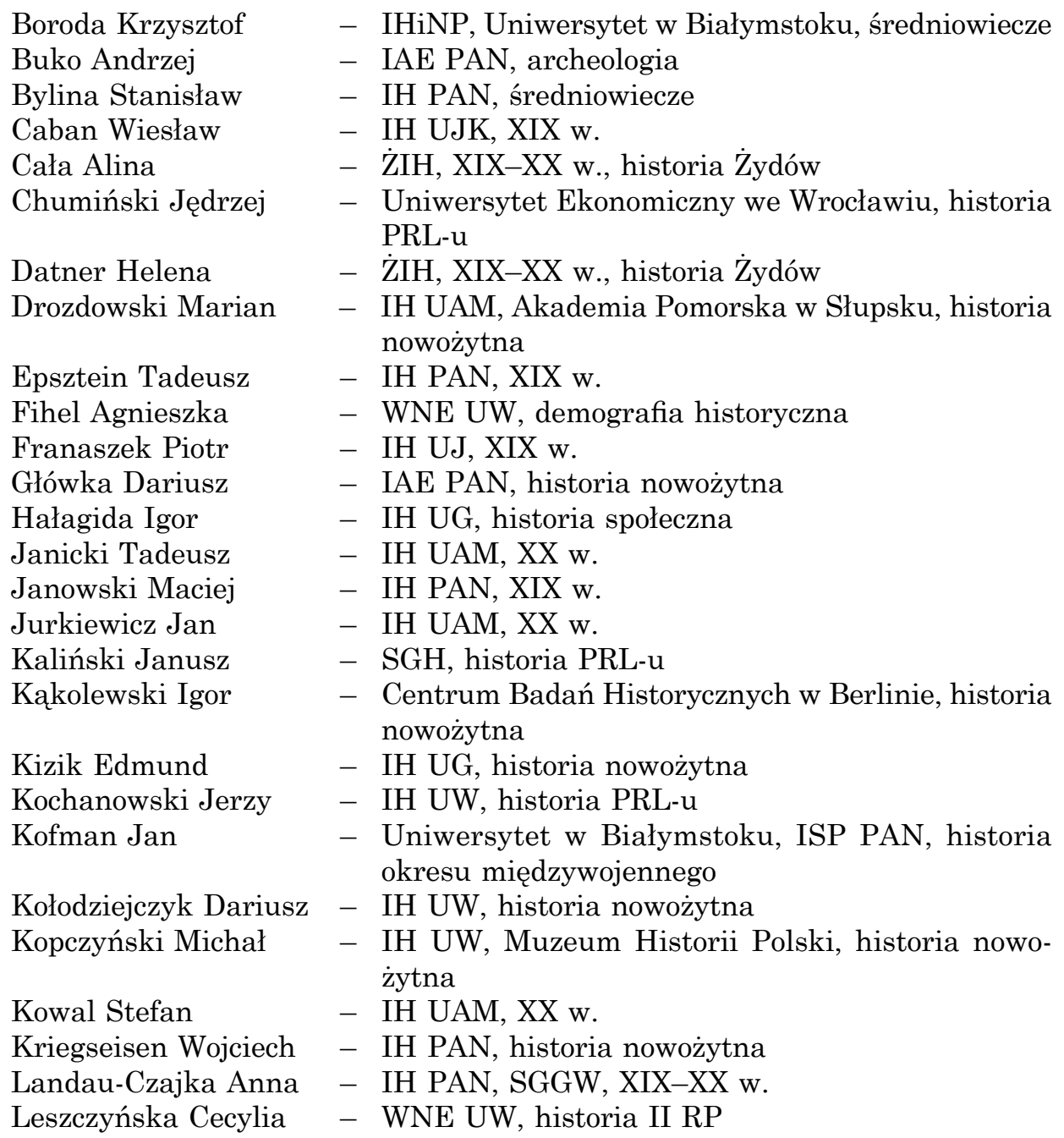


Manikowska Halina - IH PAN, średniowiecze

Molik Witold

- IH UAM, XIX w.

Przeniosło Marek

Słoń Marek

- IH UJK, historia I wojny światowej

Stola Dariusz

- IH PAN, średniowiecze

Tymiński Maciej

- ISP PAN, Collegium Civitas, historia PRL-u

Zaremska Hanna

- WNE UW, historia PRL-u

Zasztowt Leszek

- IH PAN, średniowiecze, historia Żydów

- IHN PAN, historia nauki 